\title{
Analisis penerimaan pajak bumi dan bangunan-P2 serta pengaruhnya terhadap pendapatan daerah Kabupaten/Kota di Provinsi Jambi
}

\author{
Budi Setiawan*; M. Rachmad R; Arman Delis \\ Prodi Magister Ilmu Ekonomi, Program Pascasarjana, Universitas Jambi \\ *E-mail korespodensi: budisetiawan.zee@gmail.com
}

\begin{abstract}
This study aims to analyze the determinants of $P B B-P 2$ revenue, to determine the effect of $P B B-P 2$ revenue on regional revenue and to formulate strategies for increasing $P B B$ $P 2$ revenue in Jambi Province. The data used in this study is secondary data with the type of Time series 2014-2018 data and Cross Section 11 districts/cities that come from the Central Statistics Agency and Regency / City BPPRD. This study uses Panel Data Regression Analysis and uses Simple Linear Regression using the E-Views 8.0 tool. The results of this study indicate that $P B B-P 2$ always increases every year. From the results of panel data regression analysis, the results show that investment, economic growth, and taxpayers together have a significant effect on PBB-P2 with an $R$ square value of 0.924, the Prob value ( $F$ - statistic) 0,000 and the F-statistic value is 26,556. The effect of investment on $P B B-P 2$ has a positive effect, which means that if investment increases, $P B B-P 2$ will also experience an increase. Economic growth and taxpayers will have a negative effect on $P B B-P 2$ which means that the increase in $P B B-P 2$ will decrease the economic growth and taxpayers.
\end{abstract}

Keywords:PBB-P2, Panel data, Investment, Taxpayer, Economic growth, Regional revenue.

\begin{abstract}
Abstrak
Penelitian ini bertujuan untuk menganalisis faktor-faktor penentu besaran penerimaan PBB-P2, untuk menentukan pengaruh penerimaan PBB-P2 terhadap pendapatan daerah dan untuk merumuskan strategi peningkatan penerimaan PBB-P2 di Provinsi Jambi. Data yang digunakan dalam kajian ini adalah data sekunder dengan jenis data Time series 2014-2018 dan Cross Section 11 Kabupaten/Kota yang berasal dari Badan Pusat Statistika dan BPPRD Kabupaten/Kota. Penelitian ini menggunakan Analisis Regresi Data Panel, dan mengunakan Regresi Linear Sederhana dengan mengunakan alat EViews 8.0. Hasil dari penelitian ini menunjukkan bahwa PBB-P2 selalu meningkat setiap tahunnya dari hasil analisa regresi data panel diperoleh hasil bahwa Investasi, Pertumbuhan Ekonomi, dan Wajib Pajak secara bersama berpengaruh signifikan terhadap PBB-P2 dengan nilai R square sebesar 0,924, nilai Prob (F-statistic) 0,000 dan nilai F-statistik senilai 26,556. Pengaruh investasi terhadap PBB-P2 berpengaruh positif yang berarti apabila investasi mengalami kenaikan maka PBB-P2 juga akan mengalami kenaikan, Pertumbuhan ekonomi dan Wajib Pajak berpengaruh negatif terhadap PBBP2 yang berarti semakin meningkat PBB-P2 maka Pertumbuhan Ekonomi dan Wajib Pajak akan menurun.
\end{abstract}

Kata kunci: PBB-P2, Investasi, Wajib pajak, Pertumbuhan ekonomi, Pendapatan daerah. 


\section{PENDAHULUAN}

Otonomi daerah menyebabkan terjadinya pergeseran paradigma dari sistem pemerintahan yang bercorak sentralisasi mengarah kepada sistem pemerintahan yang desentralisasi yaitu dengan memberikan keleluasaan kepada daerah dalam mewujudkan daerah otonom yang luas dan bertanggung jawab untuk mengatur dan mengurus kepentingan masyarakat setempat sesuai kondisi dan potensi wilayahnya. Pemberian otonomi kepada daerah pada dasarnya bertujuan meningkatkan daya guna dan hasil guna penyelenggaraan pemerintah daerah terutama dalam pelaksanakan pembangunan dan pelayanan terhadap masyarakat sebagaimana yang diatur dalam Undang-Undang Nomor 9 Tahun 2015, tentang perubahan Undang-Undang 23 Tahun 2014 tentang Pemerintahan Daerah.

Penyelenggaraan otonomi daerah juga harus dapat menjamin keserasian hubungan satu daerah dengan daerah lain/hubungan antar daerah. Artinya, mampu dibangun suatu bentuk kerjasama antar daerah dalam rangka mencegah ketimpangan antara satu daerah dengan daerah lain. Hal yang tidak kalah pentingnya bahwa otonomi daerah juga harus mampu menjamin hubungan yang serasi antara daerah dengan pemerintah pusat, sehingga mampu memelihara dan menjaga keutuhan wilayah negara dan tetap tegaknya NKRI dalam rangka mewujudkan tujuan negara, maka daerah harus mampu mengelola dan menggali sumber-sumber pendapatan daerah agar dapat menyelenggarakan urusan pemerintahan daerah secara optimal.

Dengan adanya asas otonomi daerah, daerah diharapkan dapat mandiri untuk menggali, mengelola sumber-sumber pendapatan daerah secara optimal guna meningkatkan kesejahteraan masyarakat. Untuk mendukung penyelenggaraan otonomi daerah, maka dibutuhkan sumber-sumber penerimaan daerah, sebagaimana tercantum dalam Undang-Undang No 9 Tahun 2015, tentang perubahan Undang-undang No. 23 Tahun 2014 tentang pemerintahan daerah dalam Pasal 285 berasal dari pendapatan asli daerah yaitu pajak daerah, retribusi daerah, hasil pengelolaan kekayaan daerah yang dipisahkan dan lain-lain, pendapatan asli daerah yang sah serta didukung pendapatan transfer dan lain-lain, pendapatan asli daerah yang sah. Pemerintah Kabupaten atau Kota di dalam penyelenggaraan otonomi daerah untuk meningkatkan pendapatan asli daerahnya harus mengelolah sumber-sumber pendapatan daerahnya dengan sebaik mungkin, karena dengan semakin meningkatnya Pendapatan Asli Daerah maka Anggaran Pendapatan dan Belanja Daerah (APBD) akan meningkat pula. Salah satunya yakni dengan meningkatkan Pendapatan Asli Daerah dari sektor pajak khususnya jenis Pajak Bumi dan Bangunan Perdesaan dan Perkotaan (PBB-P2) yang kini kewenangannya telah dialihkan dari Pemerintah Pusat kepada Pemerintah Daerah, dengan berbagai pertimbangan. Pertama, secara konseptual PBB-P2 dapat dipungut oleh daerah karena lebih bersifat lokal, visabilitas, objek pajak tidak berpindah-pindah dan terdapat hubungan erat antara pembayar pajak dan yang menghasilkan pajak tersebut. Kedua pengalihan PBB-P2 kepada daerah dapat meningkatkan PAD dan memperbaiki struktur APBD.

Pada Peraturan Pemerintah Nomor 91 Tahun 2010 tentang Jenis Pajak Daerah yang dipungut Berdasarkan Penetapan Kepala Daerah atau dibayar sendiri oleh Wajib Pajak, dijelaskan mengenai pembagian wewenang pungutan pajak daerah baik yang dikelola provinsi maupun kabupaten/kota. Dalam pasal 2 disebutkan bahwa jenis pajak untuk Kabupaten/Kota adalah terdiri dari pajak hotel, pajak restoran, pajak hiburan, pajak reklame, pajak penerangan jalan, pajak mineral bukan logam dan batuan, pajak parkir, pajak air tanah pajak sarang burung walet, pajak bumi dan bagunan perdesaan dan perkotaan, serta bea perolehan hak atas tanah dan bangunan.

Undang-Undang Nomor 28 Tahun 2009 pada bab I Pasal 1 Ayat 40 menyebutkan bahwa, "Nilai Jual Objek Pajak, yang selanjutnya di singkat NJOP, adalah harga ratarata yang diperoleh dari transaksi jual beli yang terjadi secara wajar, dan bilamana tidak 
terdapat transaksi jual beli, NJOP ditentukan melalui perbandingan harga dengan objek lain yang sejenis, atau nilai perolehan baru, atau NJOP pengganti”, Undang-Undang Nomor 28 Tahun 2009 pada Bab I Pasal 1 Ayat 37, 38, 39 secara garis besar menyatakan bahwa, Pajak Bumi dan Bangunan Perdesaaan dan Perkotaan adalah pajak atas bumi dan/atau bangunan yang dimiliki, dikuasai, dan/atau dimanfaatkan oleh orang pribadi atau badan, kecuali kawasan yang digunakan untuk kegiatan usaha perkebunan, perhutanan, dan pertambangan. Bumi adalah permukaan bumi yang meliputi tanah dan perairan pedalaman serta laut wilayah kabupaten/kota, sedangkan Bangunan adalah kontruksi teknik yang ditanam atau dilekatkan secara tetap pada tanah dan/atau perairan pedalaman dan/atau laut.

Kebijakan pengalihan ini mengubah fungsi Direktorat Jenderal Pajak yang dahulunya sebagai pihak pengelola pendapatan negara atas Pajak Bumi dan Bangunan. kini menjadi pendamping serta pengompilasi dari peraturan dan kebijakan Pajak Bumi dan Bangunan Perdesaan dan Perkotaan (PBB-P2) untuk digunakan sebagai pedoman pemerintah daerah dalam mengelola pajak PBB-P2. Hal ini sebagaimana dijelaskan dalam peraturan bersama Menteri Keuangan dan Menteri Dalam Negeri No. 15/PMK.07/2014 dan No. 10 Tahun 2014, tentang tahapan persiapan dan pelaksanaan Pengalihan Pajak Bumi dan Bangunan Perdesaan dan Perkotaan sebagai pajak daerah. Setelah ditetapkannya Undang-Undang No. 28 Tahun 2009 mengenai Pajak Daerah dan Retribusi Daerah bulan Januari 2014, maka Pajak Bumi dan Bangunan Perdesaan dan Perkotaan (PBB-P2) resmi menjadi kewenangan pemerintah Kabupaten/Kota. Semua tahapan kebijakan PBB-P2 menjadi tanggung jawab pemerintah daerah.

Rata-rata target penerimaan pajak bumi dan bangunan sektor Perdesaan dan Perkotaan yang tertinggi terdapat pada Kota Jambi sebesar Rp30.896.000.000, sedangkan yang terendah terdapat pada Kabupaten Kerinci bahwa rata-rata target penerimaan pajak bumi dan bangunan sektor perdesaan dan perkotaan sebesar Rp530.000.000, Pada Kabupaten Merangin sebesar Rp3.186.445.210, kemudian pada Kabupaten Sarolangun sebesar Rp624.393.876, selanjutnya pada Kabupaten Batang Hari sebesar Rp2.826.000.000, pada Kabupaten Muaro Jambi sebesar Rp5.717.933.400, pada Kabupaten Tanjung Jabung Timur sebesar Rp1.962.490.190, pada Kabupaten Tanjung Jabung Barat sebesar Rp4.014.015.041, pada Kabupaten Tebo Rp2.283.658.760, pada Kabupaten Bungo sebesar Rp3.240.000.000, dan pada Kota Sungai Penuh sebesar Rp624.566.498.

Rata-rata realisasi penerimaan pajak Bumi dan Bangunan sektor perdesaan dan perkotaan yang tertinggi terdapat pada Kota Jambi sebesar Rp20.107.671.39, Sedangkan yang terendah terdapat pada Kota Sungai Penuh yaitu sebesar Rp388.686.374, kemudian pada Kabupaten Kerinci sebesar Rp419.156.628, bahwa ratarata Realisasi Penerimaan Pajak Bumi dan Bangunan sektor Perdesaan dan Perkotaan pada Kabupaten Merangin sebesar Rp1.752.407.839, Kabupaten Sarolangun sebesar Rp889.544.157, selanjutnya pada Kabupaten Batang Hari sebesar Rp1.965.883.369, pada Kabupaten Muaro Jambi sebesar Rp4.792.512.412, pada Kabupaten Tanjung Jabung Timur sebesar Rp1.694.014.951, pada Kabupaten Tanjung Jabung Barat sebesar Rp4.626.833.235, pada Kabupaten Tebo Rp1.824.239.900 dan Kabupaten Bungo sebesar Rp3.002.648.700.

Pengalihan PBB-P2 ke Pemerintah Kabupaten/Kota belum berjalan maksimal. Hal ini dilihat dari hasil pemungutan pajak dari Januari hingga Juli 2014 bahwa pemungutan PBB-P2 tidak mencapai realisasi yang telah ditentukan bahkan realisasi pada tahun berjalan lebih kecil dari tahun sebelumnya. Padahal seharusnya dengan pengalihan PBB-P2 menjadi wewenang Pemerintah Kabupaten/Kota dapat memaksimalkan jumlah pemungutan PBB-P2, sehingga dapat meningkatkan PAD Kabupaten/Kota Provinsi Jambi. 
Rendahnya realisasi pajak tersebut bisa terjadi karena dua faktor yaitu pada Penentuan Target Penerimaan Pajak dan Mekanisme Pemungutan Pajak. Penentuan target penerimaan Pajak Bumi dan Bangunan selama ini dilakukan berdasarkan pendekatan inkramental atau dinaikkan targetnya dari tahun sebelumnya. Hal ini dikarenakan metode yang digunakan dalam pendekatan inkramental ini dilakukan melalui perhitungan realisasi penerimaan pada tahun sebelumnya dengan penyesuaian terhadap kebutuhan APBD yang disesuaikan dengan pertumbuhan ekonomi dan tingkat inflasi yang terjadi untuk menentukan target penerimaan pada tahun selanjutnya, artinya penentuan target penerimaan pajak bukan berdasarkan potensi penerima dengan memperhatikan rasio proporsi dan rasio pertumbuhan, hal ini dikarenakan potensi penerimaan PBB-P2 belum dihitung secara menyeluruh. Mekanisme Pemungutan PBBP2 yang dilaksanakan Pemerintah Kabupaten/Kota Provinsi Jambi melibatkan pihak kecamatan dan kelurahan yang masih berjalan secara manual. Sementara dengan jumlah wajib pajak yang tidak sedikit di setiap kecamatan dan kelurahan seharusnya dikelola dengan menggunakan sebuah sistem manajemen teknologi informasi yang menunjang proses pelaksanaan pemungutan PBB-P2, untuk mengatasi pemungutan PBB-P2 yang belum mencapai target.

Berdasarkan uraian diatas, penulis tertarik untuk membahas mengenai pengalihan PBB-P2 dari Pemerintah Pusat ke Pemerintahan Daerah khususnya di Pemerintahan Kabupaten/Kota, Dibutuhkan kesadaran masyarakat untuk membayar PBB-P2, karena dengan membayar pajak, masyarakat telah membantu pembangunan di Kabupaten/Kota serta didukung oleh Aparat Penyelenggara Pemerintahan. Sehingga menjadi penting dilakukan Penelitian "Analisis Penerimaan Pajak Bumi dan Bangunan-P2 serta Pengaruhnya terhadap Pendapatan Daerah Kabupaten/Kota di Provinsi Jambi”

\section{METODE}

\section{Metode penelitian}

Penelitian ini menggunakan data sekunder dengan jenis data time series 20142018 dan cross section 11 Kabupaten/ Kota di Provinsi Jambi. Data sekunder merupakan sumber data yang tidak memberikan informasi secara langsung kepada pengumpul data. Sumber data sekunder ini dapat berupa hasil pengolahan lebih lanjut dari data primer yang disajikan dalam bentuk lain atau dari orang lain (Sugiyono, 2012). Teknik analisis yang digunakan dalam penelitian ini adalah analisis deskriptif kualitatif dan kuantitatif yang akan dijelaskan sebagai berikut.

\section{Model analisis pertama}

Untuk menjawab tujuan penelitian pertama digunakan analisis regresi data panel. Data panel (pooled data) merupakan data yang mengkombinasikan antara data deret waktu (time series) dan data kerat lintang (cross section). Data deret waktu (time series) adalah data observasi pada satu subjek penelitian diamati dalam satu periode waktu, misalnya selama lima tahun. Sedangkan data kerat lintang (cross section) adalah data observasi pada beberapa subjek penelitian dalam satu waktu, misalnya dalam satu tahun atau satu periode tertentu yang sama. Dalam data panel, observasi dilakukan pada beberapa subjek dianalisis dari waktu ke waktu. Persamaan model dengan menggunakan data cross section dapat ditulis sebagai berikut.

$$
\mathbf{Y i}=\beta 0+\beta 1 \mathrm{Xi}+\varepsilon \mathbf{i} ; \mathbf{i}=1,2,3, \ldots, \mathrm{N}
$$


Dimana $\mathrm{N}$ adalah banyaknya data cross section. Sedangkan persamaan model dengan time series dapat ditulis sebagai berikut.

$$
\mathbf{Y t}=\boldsymbol{\beta 0}+\boldsymbol{\beta 1} \mathbf{X t}+\varepsilon \mathbf{t} ; \mathrm{t}=1,2,3, \ldots, \mathbf{T}
$$

Dimana $\mathrm{T}$ adalah banyaknya data time series. Hubungan antar variabel secara fungsional dinyatakan sebagai berikut:

\section{PBB $=\mathbf{f}\{$ WP, INV, PDRB, $\}$}

Sehingga persamaan data panel merupakan pengkombinasian dari persamaan cross section dan time series dapat ditulis sebagai berikut.

$$
\text { Yit }=\beta 0+\beta 1 \text { Xit }+\varepsilon i t ; i=1,2,3, \ldots, N ; t=1,2,3, \ldots, T
$$

Dimana $\mathrm{Y}$ adalah variabel dependen, $\mathrm{X}$ adalah variabel independen, $\mathrm{N}$ adalah banyaknya observasi, $\mathrm{T}$ adalah banyaknya waktu, dan $\mathrm{N}$ x $\mathrm{T}$ adalah banyaknya data panel. Oleh karena itu, variabel-variabel dalam penelitian ini diaplikasikan dalam sebuah model, sebagai berikut.

$$
\mathrm{PBB}_{i t}=\alpha+\beta_{1} \mathrm{WP}_{\text {it }}+\beta_{2} \mathrm{INV}_{\text {it }}+\beta_{3} \mathrm{PDRB}_{\text {it }}+{ }_{\text {it }} \mu_{\mathrm{i}}
$$

Dimana:

$\begin{array}{lll}\alpha & = & \text { Koefisien intersep } \\ \beta & = & \text { Slope atau Koefisien slope } \\ \mathrm{PBB} & = & \text { Penerimaan PBB Kabupaten Kota di Provinsi Jambi } \\ \mathrm{WP} & = & \text { Jumlah wajib pajak Kabupaten Kota di Provinsi Jambi } \\ \mathrm{INV} & = & \text { Investasi Kabupaten Kota di Provinsi Jambi } \\ \mathrm{PDRB} & = & \text { PDRB Kabupaten Kota di Provinsi Jambi } \\ \mathrm{i} & = & 1,2 \ldots \mathrm{N}(\text { individu) } \\ \mathrm{t} & = & 1,2 \ldots \mathrm{T}(\text { Waktu) } \\ \mu & = & \text { errorterm }\end{array}$

\section{Model analisis kedua}

Untuk menjawab analisis kedua yaitu dengan mengunakan Regresi Linear Sederhana Dimana Y adalah variabel dependen atau, X adalah variabel independen, variabel dalam penelitian ini diaplikasikan dalam sebuah model, sebagai berikut.

$$
\begin{aligned}
& Y=\alpha+\beta_{1} \\
& \text { PBB-P2 }=\alpha+\beta_{1} P D+\mu
\end{aligned}
$$

\section{Dimana:}

$\alpha=$ Koefisien intersep

$\beta=$ Slope atau Koefisien slope

PBB = Penerimaan PBB Kabupaten Kota di Provinsi Jambi

$\mathrm{PD}=$ Pendapatan Derah

$\mu \quad=$ error term

\section{Model analisis ketiga}

Analisis situasi yang dipakai adalah Analisis SWOT. Penelitian menunjukkan bahwa kinerja perusahaan dapat ditentukan oleh kombinasi faktor internal Strength dan Weakneses dan external Opportunities dan Threats. Kedua faktor tersebut harus 
dipertimbangkan dalam analisis SWOT yang membandingkan antara faktor Peluang Eksternal (opportunities) dan Ancaman (threats) dengan faktor Kekuatan Internal (strengths) dan Kelemahan (weaknesses).

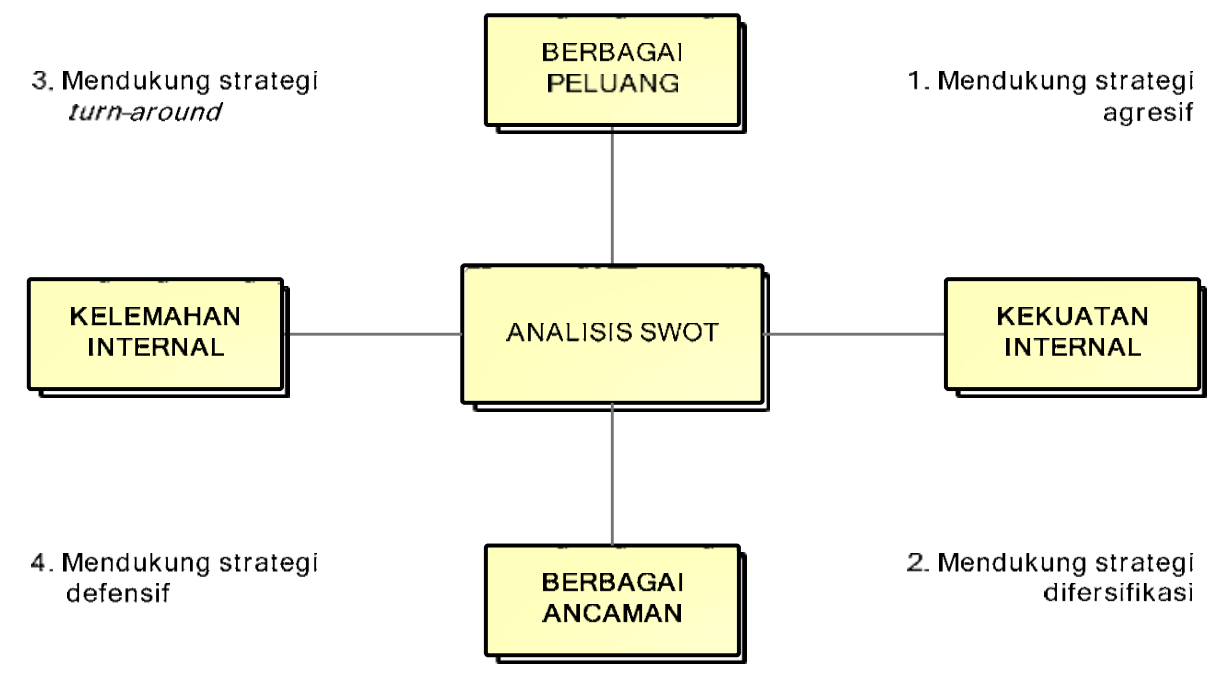

Gambar 1. Analisis SWOT

\section{HASIL DAN PEMBAHASAN}

\section{Analisis faktor- faktor penentu besaran penerimaan PBB-P2}

Dalam mengestimasi metode regresi data panel terdapat beberapa metode yang biasa digunakan yaitu common effect model, fixed effect model, dan random effect model. Untuk memilih yang mana model regresi yang paling tepat dari penelitan ini menggunakan uji chow dan hausman. Hasil dari uji chow untuk menentukan model regresi yang lebih tepat digunakan antara model common effect model dan fixed effect model, uji hausman untuk menentukan model regresi yang lebih tepat digunakan antara fixed effect model, dan random effect model.

\section{Uji Chow}

Uji chow digunakan untuk mengetahui apakah fixed effect model lebih baik dibandingkan dengan common effect model dilakukan dengan uji F-Statistik. Berdasarkan pengujian yang telah dilakukan maka di peroleh hasil nilai F-Statistik berikut ini.

Tabel 1. Uji Chow model PLS dengan FEM

\begin{tabular}{lrrr}
\hline Effects Test & Statistic & d.f. & Prob. \\
\hline \hline Cross-section F & 27.386834 & $(10,41)$ & 0.0000 \\
Cross-section Chi-square & 112.122038 & 10 & 0.0000 \\
\hline
\end{tabular}

Sumber: Data diolah,2020

Berdasarkan tabel 2 diatas, dapat dilihat bahwa nilai probabilitas chi-square $=$ $0.0000<0,05$. Sehingga HO ditolak dan HI diterima, artinya model fixed effect yang harus digunakan dalam penelitian ini. Namun, sebelum melakukan analisis model lebih lanjut maka perlu dilakukan uji Hausman untuk memperoleh model yang paling tepat. 


\section{Uji hausman}

Hausman test ini bertujuan untuk membandingkan antara metode fixed effect dan metode random effect. Hasil dari pengujian dengan menggunakan tes ini adalah mengetahui metode mana yang sebaiknya dipilih. Berikut merupakan output dari uji menggunakan Hausman Test.

Tabel 2 Hasil uji model menggunakan Hausman test

\begin{tabular}{lcrc}
\hline \hline Test Summary & Chi-Sq. Statistic & Chi-Sq. d.f. & Prob. \\
\hline \hline Cross-section random & 3.739022 & 3 & 0.0211 \\
\hline \hline
\end{tabular}

Sumber: Data diolah, 2020

Berdasarkan hasil uji hausman diatas dapat dilihat bahwa hasil pengujian chisquare statistic sebesar $3.739022>$ chi square sebesar 1 dan p-value signifikan sebesar $0.0211<0.05$ maka H1 diterima sehingga fixed effect model lebih tepat untuk mengestimasi data panel.

\section{Hasil uji hipotesis}

Pemilihan model yang telah dilakukan maka fixed effect model terpilih menjadi model terbaik untuk mengestimasi.

Tabel 3. Hasil uji regresi fixed effect model

\begin{tabular}{|c|c|c|c|c|}
\hline Variable & Coefficient & Std. Error & t-Statistic & Prob. \\
\hline $\mathrm{C}$ & -5.442801 & 2.062366 & -2.639106 & 0.0121 \\
\hline LOG(INV) & 1.369453 & 0.247983 & 5.522372 & 0.0000 \\
\hline PE & 0.016517 & 0.042312 & 0.390371 & 0.6985 \\
\hline LOG(WP) & 0.929025 & 0.271620 & 3.420309 & 0.0015 \\
\hline \multicolumn{5}{|c|}{ Effects Specification } \\
\hline \multicolumn{5}{|c|}{$\begin{array}{l}\text { Cross-section fixed (dummy variables) } \\
\text { Period fixed (dummy variables) }\end{array}$} \\
\hline R-squared & 0.923970 & \multirow{7}{*}{\multicolumn{2}{|c|}{$\begin{array}{l}\text { Mean dependent var } \\
\text { S.D. dependent var } \\
\text { Akaike info criterion } \\
\text { Schwarz criterion } \\
\text { Hannan-Quinn criter. } \\
\text { Durbin-Watson stat }\end{array}$}} & 21.37611 \\
\hline Adjusted R-squared & 0.889038 & & & 1.078729 \\
\hline S.E. of regression & 0.359335 & & & 1.049007 \\
\hline Sum squared resid & 4.777501 & & & 1.705952 \\
\hline Log likelihood & -10.84769 & & & 1.303053 \\
\hline F-statistic & 26.45019 & & & 1.996613 \\
\hline $\operatorname{Prob}(F-$-statistic $)$ & 0.000000 & & & \\
\hline
\end{tabular}

Sumber: Data diolah, 2020

Berdasarkan perhitungan dengan mengunakan eviews 9 diperoleh nilai-nilai koefisien regresi, dapat dibentuk suatu persamaan regresi sebagai berikut :

$$
\begin{aligned}
& \log (\mathrm{PBB})=-5.442801+1.369453 \log (\operatorname{Inv})+0.016517 \mathrm{PE}+0.929025 \log (\mathrm{WP}) \\
& {[0,000] \quad[0,6985] \quad[0,0015]}
\end{aligned}
$$


Dimana Dari hasil regresi diatas angka didalam kurung (....) menunjukkan thitung sedangkan angka didalam kurung [.....] menunjukkan probabilita, dari hasil regresi diatas dapat dilihat bahwa antar variabel bebas, yang dalam kaitan ini diduga bahwa Investasi dan wajib pajak memiliki pengaruh yang signifikan sedangkan variabel pertumbuhan ekonomi tidak pengaruh signifikan.

\section{Koefisien determinasi ( $\mathbf{U j i} \mathbf{R}^{2}$ )}

Analisis koefisien determinasi ganda digunakan untuk mengetahui seberapa besar kontribusi variabel bebas terhadap variabel terikat. Secara bersama-sama ekonometrik nilai $\mathrm{R}^{2}$ variabel bebas secara bersama-sama yaitu 0,923970 artinya kontribusi variabel bebas terhadap variabel terikat adalah sebesar 92,39 persen sedangkan sisanya lagi 7,61 persen dipengaruhi oleh faktor lain yang tidak dimasukkan kedalam penelitian ini.

\section{Uji F (Uji simultan)}

Pengujian ini dilakukan untuk mengetahui apakah semua variabel bebas berpengaruh terhadap variabel terikat. Uji f diperoleh dengan membandingkan F-hitung dengan F-tabel pada tarif $(a=0,05)$ dengan melihat probabilitasnya dengan mengunakan eviews hasil diperoleh untuk f-hitung adalah sebesar 26.45019 sedangkan nilai Ftabelnya 2,79 dengan demikian dapat dilihat bahwa f-hitung > f-tabel. Jadi, nilai fHitung > F-tabel, maka Ho di tolak. Maka dapat disimpulkan bahwa investasi, pertumbuhan ekonomi dan wajib pajak secara bersama-sama berpengaruh signifikan terhadap PBB-P2 dikabupaten/kota Provinsi Jambi.

\section{Uji t (Uji parsial)}

Nilai dalam pengujian hipotesis terhadap koefisien regresi secara parsial ditentukan dengan mengunakan tabel distribusi normal dengan tingkat signifikan $(\mathrm{a}=$ $5 \%$ ) dengan tingkat kepercayaan 95\% dan dengan derajat kebebasan ( $\mathrm{df}=55)$, diperoleh $\mathrm{t}$ tabel sebesar 2.79 yang akan dibandingkan dengan t hitung.

Uji t statistik untuk variabel Investasi diketahui bahwa t-hitung > t-tabel (5.522372 > 2.00758) maka Ho ditolak dan Ha diterima. Artinya variabel Investasi berpengaruh signifikan terhadap PBB-P2 di Provinsi Jambi.

Uji t-statistik untuk variabel Pertumbuhan Ekonomi diketahui bahwa t-hitung < t-tabel $(0.390371<2.00758)$ maka Ho diterima dan Ha ditolak, artinya variabel Pertumbuhan Ekonomi tidak berpengaruh signifikan terhadap PBB-P2 di Provinsi Jambi.

Uji t-statistik untuk variabel Wajib Pajak diketahui bahwa t-hitung < t-tabel (3.420309 > 2.00758 ) maka Ho diterima dan Ha ditolak, artinya variabel Wajib Pajak berpengaruh signifikan terhadap PBB-P2 di Provinsi Jambi.

\section{Pengaruh PBB-P2 terhadap pendapatan daerah}

Dalam mengestimasi metode regresi data panel terdapat beberapa metode yang biasa digunakan yaitu common effect model, fixed effect model, dan random effect model. Untuk memilih yang mana model regresi yang paling tepat dari penelitan ini maka pengujian menggunakan uji Chow dan Hausman. Hasil dari uji Chow dilakukan untuk menentukan model regresi yang lebih tepat digunakan antara model common effect model dan fixed effect model, sedangkan untuk uji Hausman dilakukan untuk 
menentukan model regresi yang lebih tepat digunakan antara fixed effect model, dan random effect model.

\section{Uji Chow}

Uji Chow digunakan untuk mengetahui apakah fixed effect model lebih baik dibandingkan dengan common effect model dilakukan dengan uji F-Statistik. Berdasarkan pengujian yang telah dilakukan maka di peroleh hasil nilai F-Statistik berikut ini.

Tabel 4. Uji Chow model PLS dengan FEM

\begin{tabular}{lrrr}
\hline \hline Effects Test & Statistic & d.f. & Prob. \\
\hline \hline Cross-section F & 220.658253 & $(10,39)$ & 0.0000 \\
Cross-section Chi-square & 222.923723 & 10 & 0.0000 \\
Period F & 4.044606 & $(4,39)$ & 0.0077 \\
Period Chi-square & 19.085570 & 4 & 0.0008 \\
Cross-Section/Period F & 168.142616 & $(14,39)$ & 0.0000 \\
Cross-Section/Period Chi-square & 226.420702 & 14 & 0.0000 \\
\hline \hline
\end{tabular}

Sumber: Data diolah, 2020

Berdasarkan Tabel 4 diatas, dapat dilihat bahwa nilai probabilitas chi-square $=$ $0.0000<0,05$. Sehingga $\mathrm{H}_{\mathrm{O}}$ ditolak dan $\mathrm{H}_{\mathrm{I}}$ diterima, artinya model common effect yang harus digunakan dalam penelitian ini. Namun, sebelum melakukan analisis model lebih lanjut maka perlu dilakukan uji Hausman untuk memperoleh model yang paling tepat

\section{Uji hausman}

Hausman test ini bertujuan untuk membandingkan antara metode fixed effect dan metode random effect. Hasil dari pengujian dengan menggunakan tes ini adalah mengetahui metode mana yang sebaiknya dipilih. Berikut merupakan output dari uji menggunakan Hausman Test.

Tabel 5. Hasil uji model menggunakan Hausman test

\begin{tabular}{lccc}
\hline \hline Test Summary & Chi-Sq. Statistic Chi-Sq. d.f. & Prob. \\
\hline \hline Cross-section random & 0.000000 & 1 & 1.0000 \\
Period random & 5.791563 & 1 & 0.0161 \\
$\begin{array}{l}\text { Cross-section and period } \\
\text { random }\end{array}$ & 11.593061 & 1 & 0.0007 \\
\hline \hline
\end{tabular}

Sumber: Data diolah, 2020

Berdasarkan hasil uji hausman diatas dapat dilihat bahwa hasil pengujian chisquare statistic sebesar $0.000000<$ chi square sebesar 1 dan p-value signifikan sebesar $1.0000>0.05$ maka $\mathrm{H}_{0}$ ditolak sehingga fixed effect dan random tidak tepat untuk mengestimasi data panel.

\section{Hasil uji hipotesis}

Pemilihan model yang telah dilakukan maka Fixed effect model terpilih menjadi model terbaik untuk mengestimasi. 
Tabel 6. Hasil uji regresi fixed effect model

\begin{tabular}{lrlrr}
\hline \multicolumn{1}{c}{ Variable } & Coefficient & Std. Error & t-Statistic & Prob. \\
\hline \multicolumn{1}{c}{ C } & -79.80873 & 13.66020 & -5.842428 & 0.0000 \\
\multicolumn{1}{c}{ LOG(PD) } & 3.652133 & 0.493096 & 7.406540 & 0.0000 \\
\hline \hline & 0.508608 & Mean dependent var & 21.36311 \\
R-squared & 0.499336 & S.D. dependent var & 1.096932 \\
Adjusted R-squared & 0.776163 & Akaike info criterion & 2.366776 \\
S.E. of regression & 31.92870 & Schwarz criterion & 2.439770 \\
Sum squared resid & -63.08635 & Hannan-Quinn criter. & 2.395004 \\
Log likelihood & 54.85684 & Durbin-Watson stat & 0.504936 \\
F-statistic & 0.000000 & & \\
Prob(F-statistic) & & & \\
\hline Surber:Data & & &
\end{tabular}

Sumber: Data diolah, 2020

Berdasarkan perhitungan dengan mengunakan eviews 9 diperoleh nilai-nilai koefisien regresi, dapat dibentuk suatu persamaan regresi sebagai berikut :

$\log (\mathrm{PBB})=-79.80873+3.652133 \log (\mathrm{PD})$

\section{Koefisien determinasi (Uji $\mathbf{R}^{2}$ )}

Analisis koefisien determinasi ganda digunakan untuk mengetahui seberapa besar kontribusi variabel bebas terhadap variabel terikat. Secara bersama-sama ekonometrik nilai $\mathrm{R}^{2}$ variabel bebas secara bersama-sama yaitu 0.508608 artinya kontribusi variabel bebas terhadap variabel terikat adalah sebesar 50,86 persen sedangkan sisanya lagi 49,14 persen dipengaruhi oleh faktor lain yang tidak dimasukkan kedalam penelitian ini.

\section{Uji F (Uji simultan)}

Pengujian ini dilakukan untuk mengetahui apakah semua variabel bebas berpengaruh terhadap variabel terikat. Uji f diperoleh dengan membandingkan F-hitung dengan $\mathrm{F}$-tabel pada tarif $(\mathrm{a}=0,05)$ dengan melihat probabilitasnya.dengan mengunakan eviews hasil diperoleh untuk f-hitung adalah sebesar 54.85684 sedangkan nilai Ftabelnya 4,02 dengan demikian dapat dilihat bahwa f-hitung > f-tabel. Jadi, nilai fHitung > F-tabel, maka Ho di tolak. Maka dapat disimpulkan bahwa pendapatan daerah secara bersama-sama berpengaruh signifikan terhadap PBB-P2 di Kabupaten/Kota Provinsi Jambi.

\section{Uji t (Uji parsial)}

Nilai dalam pengujian hipotesis terhadap koefisien regresi secara parsial ditentukan dengan mengunakan tabel distribusi normal dengan tingkat signifikan $(\mathrm{a}=$ $5 \%$ ) dengan tingkat kepercayaan $95 \%$ dan dengan derajat kebebasan ( $\mathrm{df}=55)$, diperoleh $\mathrm{t}$ tabel sebesar 2.79 yang akan dibandingkan dengan $\mathrm{t}$ hitung.

Uji t statistik untuk variabel pendapatan daerah diketahui bahwa t-hitung $>\mathrm{t}$ tabel $(7.406540>2.00758)$ maka Ho ditolak dan Ha diterima. Artinya variabel pendapatan daerah berpengaruh signifikan terhadap PBB-P2 di Provinsi Jambi.

\section{Strategi meningkatkan PBB-P2}

Analisis strategi yang tepat dalam meningkatkan PBB-P2 kabupaten/kota di Provinsi Jambi dengan melakukan analisis SWOT. Analisis SWOT menggunakan berbagai model analisis dengan tahapan Identifikasi faktor internal (IFAS) dan 
Identifikasi faktor eksternal (EFAS) dalam pengelolaan PBB-P2. Berdasarkan hasil identifikasi terhadap faktor internal dalam pengelolaan PBB-P2. maka diperoleh kekuatan dan kelemahan yang terdapat pada pengelolaan PBB-P2 pada kabupaten/kota di provinsi jambi yaitu:

\section{Internal faktor analisis strategi (IFAS)}

\section{Kekuatan (S)}

Pertumbuhan ekonomi yang dinamis pada kabupaten/kota di Provinsi Jambi, Tercukupinya Jumlah Sumber Daya Manusia di Dinas Pendapatan Daerah pada kabupaten/kota di Provinsi Jambi, Sarana dan prasarana yang memadai serta sumber PBB-P2 yang mencukupi, Peraturan pemerintah yang menjadi dasar hukum.

\section{Kelemahan (W)}

Pelayanan perpajakan yang ada saat ini belum maksimal, Fasilitas yang mendukung untuk mengunjungi langsung objek pajak belum memadai, Terbatasnya jumlah tenaga ahli perpajakan di Dinas Pendapatan Daerah, Intensitas Sosialisasi terhadap masyarakat masih kurang maksimal, Tata administrasi pajak yang masih belum optimal, Kurangnya sinergisitas koordinasi antara pihak terkait.

\section{Eksternal faktor analisis strategy (EFAS)}

\section{Peluang}

Adanya kejelasan hukum berupa PERDA (Peraturan Daerah), Mudahnya akses koordinasi antar pihak terkait, mulai dari tingkat kecamatan, hingga kelurahan, Tersedianya kesempatan bagi pegawai untuk mengikuti BIMTEK atau pelatihan tentang perpajakan, Pertumbuhan jumlah penduduk terus bertambah, Terbukanya peluang kerja sama dengan sektor swasta, Perkembangan teknologi dan komunikasi.

\section{Ancaman}

Budaya masyarakat yang menolak membayar pajak, Rendahnya kesadaran dan kepatuhan masyarakat dalam membayar pajak, Adanya oknum-oknum yang memanfaatkan kesempatan, Pencapaian realisasi pemerintah yang belum mencapai target yang mengakibatkan persepsi buruk di masyarakat. Berdasarkan identifikasi strategi diatas. beberapa alternatif strategi Peningkatan PBB-P2 Kabupaten/Kota Provinsi Jambi dapat dirumuskan sebagai berikut:

\section{Strategi S-O (mengunakan kekuatan dengan memanfaatkan peluang)}

Mempertahankan pertumbuhan ekonomi yang dinamis dengan mempertegas sanksi pajak karena PBB-P2 adalah pajak yang diwujudkan oleh semua elemen masyarakat, serta meningkatkan kualitas sumber daya manusia melalui bimbingan teknis atau kursus agar dapat mengoptimalkan pemanfaatan sarana dan prasarana yang ada seperti perkembangan teknologi dan komunikasi.

\section{W-O (Mengulangi kelemahan dengan memanfaatkan Peluang)}

Meningkatkan fasilitas untuk mengunjungi objek pajak serta menambah kuantitas tenaga ahli agar meningkatnya intensitas sosialisasi terhadap objek pajak dan masyarakat, serta optimalnya koordinasi antara stakeholder yang ada.

\section{S-T (Mengunakan Kekuatan untuk Mengatasi Ancaman)}

Meningkatkan sarana dan prasarana agar target realisasi pemerintah tercapai, sehingga memperbaiki persepsi masyarakat terhadap pemerintah, dan memberi sanksi tegas terhadap oknum-oknum yang memanfaatkan kesempatan. 


\section{W-T (Memperkecil Kelemahan untuk Mengatasi Ancaman)}

Memperbaiki administrasi perpajakan agar adanya kejelasan realisasi pajak dan melakukan sosialisasi kepada masyarakat agar tubuh kesadaran wajib pajak dengan mensosialisasikan bahwa realisasi pajak adalah untuk kepentingan sarana dan prasarana serta kepentingan bersama.

Tabel 7. Analisis matriks SWOT

\begin{tabular}{|c|c|c|}
\hline Faktor Eksternal & $\begin{array}{l}\text { Kekuatan (Strenghts) } \\
\text { 1. Pertumbuhan ekonomi yang dinamis } \\
\text { pada kabupaten/kota di Provinsi } \\
\text { Jambi. } \\
\text { 2. Tercukupinya Jumlah Sumber Daya } \\
\text { Manusia di Dinas Pendapatan } \\
\text { Daerah pada kabupaten/kota di } \\
\text { Provinsi Jambi. } \\
\text { 3. Sarana dan prasarana yang memadai } \\
\text { serta sumber PBB-P2 yang } \\
\text { mencukupi. } \\
\text { Peraturan pemerintah yang menjadi } \\
\text { dasar hukum. }\end{array}$ & $\begin{array}{l}\text { Kelemahan (Weakness) } \\
\text { 1. Pelayanan perpajakan yang ada saat } \\
\text { ini belum maksimal. } \\
\text { 2. Fasilitas yang mendukung untuk } \\
\text { mengunjungi langsung objek pajak } \\
\text { belum memadai. } \\
\text { 3. Terbatasnya jumlah tenaga ahli } \\
\text { perpajakan di Dinas Pendapatan } \\
\text { Daerah. } \\
\text { 4. Intensitas sosialisasi terhadap } \\
\text { masyarakat masih kurang masimal. } \\
\text { 5ata administrasi pajak yang masih } \\
\text { belum optimal. } \\
\text { 6urangnya sinergisitas koordinasi } \\
\text { antara pihak terkait. }\end{array}$ \\
\hline 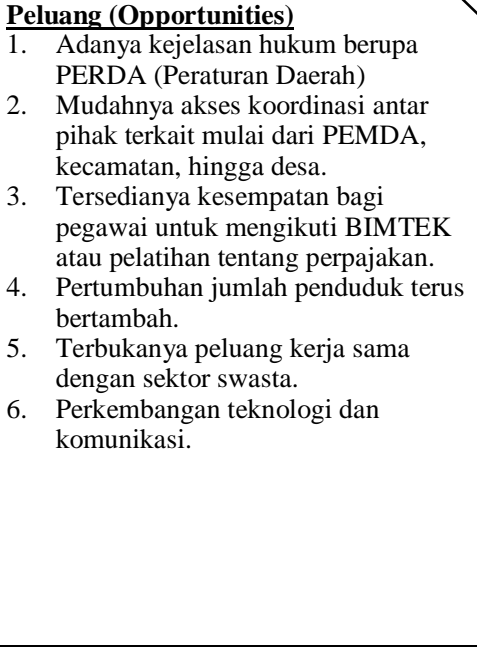 & $\begin{array}{l}\text { Strategi SO } \\
\text { - } \quad \text { Mempertahankan pertumbuhan } \\
\text { ekonomi yang dinamis dengan } \\
\text { mempertegas sanksi pajak karena } \\
\text { PBB-P2 adalah pajak yang } \\
\text { diwujudkan semua elemen } \\
\text { masyarakat. } \\
\text { (s1,o1,o2) } \\
\text { Meningkatkan Kualitas Sumber } \\
\text { Daya Manusia melalui bimbingan } \\
\text { teknis atau kursus } \\
\text { (s2,o3) } \\
\text { Mengoptimalkan penggunaan sarana } \\
\text { dan prasarana untuk mengimbangi } \\
\text { perkembangan teknologi dan } \\
\text { komunikasi } \\
\text { (s3,06) }\end{array}$ & $\begin{array}{l}\text { Strategi WO } \\
\text { Meningkatkan fasilitas untuk } \\
\text { mengunjungi objek pajak agar } \\
\text { kepercayaan masyarakat terhadap } \\
\text { pemerintah meningkat sehingga } \\
\text { penerimaan PBB-P2 menjadi } \\
\text { meningkat } \\
\text { (w2,02) } \\
\text { Meningkatkan kuantitas tenaga ahli } \\
\text { untuk mengoptimalkan sosialisasi } \\
\text { dan tata administrasi pajak. } \\
\text { (w3,o3) } \\
\text { Meningkatkan intensitas sosialisasi } \\
\text { melalui koordinasi dengan } \\
\text { pemerintah baik kecamatan maupun } \\
\text { desa } \\
\text { (w4,02) } \\
\text { Meningkatkan koordinasi dengan } \\
\text { mengoptimalkan penggunaan } \\
\text { teknologi dan media komunikasi } \\
\text { (w6,o6) }\end{array}$ \\
\hline
\end{tabular}

Sumber: Data diolah, 2020

Hasil identifikasi kekuatan, kelemahan, peluang serta ancaman yang dimiliki Kabupaten/Kota di Provinsi Jambi yang di analisis menggunakan SWOT. Identifikasi diperoleh dari hasil wawancara yang mendalam kepada SDM Dinas Pendapatan Daerah, Kecamatan, Desa dan Masyarakat. Dari hasil identifikasi tersebut, dapat dirumuskan strategi untuk meningkatkan PBB-P2 dengan analisis SWOT. Hasil analisis didasarkan pada logika yang dapat memaksimalkan kekuatan dan peluang. serta secara bersamaan dapat meminimalkan kelemahan dan ancaman. Sehingga diperoleh rumusan strategi dalam upaya meningkatkan PBB-P2 Kabupaten/Kota di Provinsi Jambi. Strategi antara lain adalah sebagai berikut : Mempertahankan pertumbuhan ekonomi yang dinamis 
dengan mempertegas sanksi, pajak karena PBB-P2 adalah pajak yang diwujudkan semua elemen masyarakat, Meningkatkan Kualitas Sumber Daya Manusia melalui bimbingan teknis atau kursus, Mengoptimalkan penggunaan sarana dan prasarana untuk mengimbangi perkembangan teknologi dan komunikasi, Meningkatkan fasilitas untuk mengunjungi objek pajak agar kepercayaan masyarakat terhadap pemerintah meningkat sehingga penerimaan PBB-P2 menjadi meningkat, Meningkatkan kuantitas tenaga ahli untuk mengoptimalkan sosialisasi dan tata administrasi pajak, Meningkatkan intensitas sosialisasi melalui koordinasi dengan pemerintah baik kecamatan maupun kelurahan/desa, Meningkatkan koordinasi dengan mengoptimalkan penggunaan terknologi dan media komunikasi, Meningkatkan sarana dan prasarana agar target realisasi pemerintah tercapai sehingga memperbaiki persepsi masyarakat terhadap pemerintah, Memberi sanksi tegas terhadap oknum-oknum yang memanfaatkan kesempatan, Memperbaiki administrasi perpajakan agar target realisasi tercapai, Meningkatkan sosialisasi terhadap masyarakat agar tumbuh kesadaran wajib pajak.

Strategi merupakan alat yang digunakan untuk mencapai tujuan jangka panjang yang sudah ditetapkan. Salah satu strategi yang perlu diterapkan adalah dengan melibatkan masyarakat sebagai subjek utama pembangunan (Sesotyaningtyas dan Asnawi, 2015). Dalam upaya peningkatan PBB-P2 Kabupaten/Kota di Provinsi strategi yang dirumuskan mencakup pembenahan sarana prasarana, tata administrasi, maupun perbaikan SDM Dinas Pendapatan Daerah itu sendiri. Masyarakat sebagai subjek utama pembangunan ikut berpatisipasi aktif dalam proses pembangunan.

\section{Implikasi kebijakan hasil penelitian}

Berdasarkan hasil penelitian, ternyata hanya investasi dan wajib pajak yang berpengaruh terhadap penerimaan PBB-P2. ini berarti, pemerintah Kabupaten/Kota harus mendorong tumbuh kembang investasi di daerah dan penambahan wajib pajak agar penerimaan PBB-P2 meningkat, Sedangkan hasil penelitian pengaruh antara PBBP2 terhadap Pendapatan daerah menunjukkan bahwa pendapatan daerah berpengaruh positif terhadap PBB-P2 yang berarti semakin tinggi PBB-P2 maka pendapatan daerah di Kabupaten/Kota Provinsi Jambi akan meningkat, dengan meningkatnya pendapatan daerah maka akan berdampak kepada perekonomian di Kabupaten/Kota Provinsi Jambi.

Strategi peningkatan penerimaan Pajak Bumi dan Bangunan Pedesaan dan Perkotaan (PBB-P2) telah mampu dilakukan dengan baik walaupun beberapa strategi masih belum efektif dilaksanakan dikarenakan berbagai kendala yang dimiliki oleh Pemerintah Kabupaten/Kota di Provinsi Jambi, hal ini mengandung implikasi bahwa strategi peningkatan penerimaan PBB-P2 perlu dilakukan dengan menggunakan strategi yang dirumuskan melalui analisis dari faktor internal dan eksternal agar dapat mengetahui beberapa kelemahan dan ancaman yang mampu diatasi dengan adanya kekuatan dan peluang, diantara strategi-strategi tersebut adalah dengan meningkatkan intensitas sosialisasi dengan meningkatkan koordinasi dengan pemerintah kecamatan dan desa, dan juga melakukan pengawasan dan pengendalian secara sistematis dan berkelanjutan terhadap pemungutan PBB-P2 dengan melakukan evaluasi kinerja setiap tahunnya, dengan demikian penerimaan PBB-P2 diharapkan dapat optimal.

\section{KESIMPULAN DAN SARAN}

\section{Kesimpulan}

Investasi dan wajib pajak berpengaruh signifikan terhadap penerimaan PBB-P2, sedangkan pertumbuhan ekonomi tidak berpengaruh signifikan terhadap penerimaan PBB-P2. PBB-P2 berpengaruh positif dan signifikan terhadap Pendapatan Daerah tetapi kontribusinya hanya sebesar 50,86\%. 
Strategi yang dapat dilakukan untuk meningkatkan penerimaan PBB-P2 yaitu strategi meningkatkan tenaga ahli untuk mengoptimalkan sosialisasi serta tata administrasi pajak, meningkatkan intensitas sosialisasi melalui koordinasi secara langsung dengan pemerintahan kecamatan dan desa, serta strategi meningkatkan kesadaran wajib pajak dan memberi sanksi tegas bagi wajib pajak yang tidak patuh pada aturan.

\section{Saran}

Untuk menigkatkan penerimaan PBB-P2 maka pemerintah Kabupaten/Kota perlu mendorong peningkatan Investasi daerah dan jumlah wajib pajak PBB-P2. Agar Pendapatan Daerah lebih meningkat maka jumlah penerimaan PBB-P2 perlu lebih ditingkatkan agar lebih mendorong kenaikan Pendapatan Daerah yang lebih optimal untuk pembiayaan pembangunan.

\section{DAFTAR PUSTAKA}

Ayu, A., Rahayu, S., \& Junaidi. (2020). Pengaruh Kinerja Keuangan Terhadap Pertumbuhan Ekonomi Dengan Alokasi Belanja Modal Sebagai Variabel Intervening. Jurnal Akuntansi \& Keuangan Unja, 5(1), 31 - 44

Basri, H., Syaparuddin, S., \& Junaidi, J. (2013). Pemetaan Kinerja Pendapatan Asli Daerah dan Kemampuan Keuangan Daerah Kabupaten/Kota di Provinsi Jambi. Jurnal Perspektif Pembiayaan dan Pembangunan Daerah, 1(2), 81-90

Cooper dan Wiliam. (1996). Metode Penelitian Bisnis. Edisi 5. Erlangga: Jakarta:

Cooper, Donald. (2006). Metode Riset Bisnis Jilid 1. PT Media Global Edukasi: Jakarta:

Halim, Abdul. (2004). Manajemen Keuangan Daerah. AMP YKPN: Yogyakarta:

Halim, Abdul. (2012). Akuntansi Sektor Publik. Salemba Empat: Jakarta

Indah. (2013). Analisis Pelaporan dan Kontribusi Pajak Bumi dan Bangunan pada Dinas PPKAD Kabupaten Kepulauan Sangihe. Universitas Sam Ratulangi: Manado

Insukindro; Nopirin; Makhfatih. A. dan Sugiyanto, C. (1994). Evaluasi Terhadap Penentuan Tarif, NJKP, NJOP-TKP dan Peningkatan Efektivitas Pemungutan $P B B$, Kerjasama PAU SE UGM dengan Dirjen Pajak Depke, PAU SE UGM, Yogyakarta.

Junaidi, J.(2014). Statistik Deskriptif dengan Microsoft Office Excel. Fakultas Ekonomi dan Bisnis: Jambi

Kaho, Y. R. (1988). Prospek Otonomi Daerah di Negara Republik Indonesia, Fisifol UGM: Yogyakarta.

Kharisma. (2013). Analisis Efektivitas dan Kontribusi PBB terhadap Penerimaan Pajak di KPP Pratama Kota Manado. Universitas Sam Ratulangi: Manado:

Mangkoesoebroto, G.(1993). Ekonomi Publik, BPFE-UGM, Yogyakarta.

Mardiasmo. (2002). Perpajakan. Andi Offset: Yogyakarta:

Munawir. (1998). Pokok-pokok Perpajakan. Liberty: Yogyakarta:

Musgrave,R,A, and Musgrave, P.B.(1989). Public Finance in Theory and Practice. Fifth Edition. Mc. Graw-Hill International Edition: Singapore.

Soediyono, R. (1992). Ekonomi Makro: Pengantar Analisis Pendapatan Nasional, Cetakan ke II, Liberty:Yogyakarta.

Sucipto, Adi. (2013). Analisis Potensi PBB P2 di Kota Yogyakarta. Universitas Ahmad Dahlan: Yogyakarta

Suparmoko, M. (1994). Keuangan Negara dalam Teori dan Praktek, Edisi Empat, BPFE-Yogyakarta: Yogyakarta.

Suryani. (1996). Analisis Penerimaan Pajak Bumi Dan Bangunan dalam Waluyo dan Wirawan. 2000. Perpajakan. Salemba Empat: Jakarta 